\title{
ANALYSIS OF THE ASSORTMENT OF ANTIDIABETIC DRUGS AT THE PHARMACEUTICAL MARKET OF UKRAINE
}

\author{
O.V.Trygubchak \\ I.Ya.Horbachevsky Ternopil State Medical University at the Ministry of Public Health of Ukraine
}

Key words: diabetes; drugs; assortment; marketing research; pharmaceutical market

The marketing research of antidiabetic drugs presented at the pharmaceutical market of Ukraine has been conducted. The product range of the group of antidiabetic drugs has been studied according to the ATC classification, manufacturing countries and dosage forms. According to the results of the analysis 49 drugs based on insulin and its analogues for injection, and 157 oral hypoglycemic drugs have been characterized. It is noted that insulins are unevenly divided by the duration of action. Most insulin drugs are presented by human insulin. Oral hypoglycemic drugs are characterized by a high saturation within subgroups. Drugs of aldose reductase inhibitors (Isodibut under the trade name Isodibut $($ ) and other medicines, including 8 herbal medicines, are also used for treatment of diabetes. It has been found that $68 \%$ of antidiabetic drugs are imported from 21 countries of the Eurasian and South American continents. India occupies the leading positions. A wide range of antidiabetic drugs is presented by Germany, Poland, France, Denmark and Italy. The range of domestic drugs for treating diabetes is formed by 12 manufacturers. Domestic manufacturers offer only generic replacement of some active substances. At the pharmaceutical market of Ukraine antidiabetic drugs are available in the form of tablets, granules, powders, solutions and suspensions for injection. The research performed has shown that the market of antidiabetic drugs is characterized by heterogeneity of product groups, high concentration and monopolization of production, low competition and a small share of production of drugs attributable to domestic producers.

Diabetes is recognized as infectious epidemic of the XXI-th century, it takes the third place of the world's prevalence after cancer and cardiovascular diseases. The number and prevalence of people with diabetes is increasing rapidly. According to the International Diabetes Federation (IDF) in 2013 about 381.8 million people in the world had diabetes, and till 2035 this index will increase by $55 \%$ up to 591.9 million [6]. Recent data indicate that people in the countries with low and middle income represent the largest share of the epidemic ( $80 \%)$, and this disease affects much more people of the working age than previously thought. The largest number of people with diabetes is of the age from 40 to 59 years. According to the WHO data, two new cases of diabetes are diagnosed every six seconds, and one person dies because of its complications [8, 11]. In 2013, diabetes caused about 5.1 million of deaths [12]. According to the WHO in 2030 diabetes will be the seventh leading cause of death $[9,13]$.

According to the Ministry of Public Health of Ukraine in 2013 the number of patients with diabetes was over 1.3 million people, 212134 of them require daily injections of insulin [2]. Increase in prevalence of diabetes in Ukraine reached 26\% in the last 5 years [5]. A significant growth in the number of new registered cases of diabetes (primary disease) of the Ukrainian population is also observed: from 194.8 per 100 thousand of the population in 2005 to 249.8 in 2010 , i.e. $23.7 \%$ within last 5 years. However, the number of patients is increasing mainly due to diabetes mellitus type 2 [4].

In connection with the abovementioned our country intensively searches not only more effective methods of diagnosis and treatment, but also more perfect organizational methods of treatment. It creates the opportunity to reduce the incidence of adverse long-term complications on the basis of improving detection of diabetic patients. Nowadays, one of these activities being of a special attention is the rational use of modern methods of treatment and extension of the range of antidiabetic drugs [15].

\section{Materials and Methods}

The aim of this study was to conduct the marketing analysis of the range of antidiabetic drugs presented at the pharmaceutical market of Ukraine. The object of the study was the information concerning the market structure of antidiabetic drugs registered in Ukraine. The graphical methods and analysis are used in the article.

To solve this goal the study of a conjuncture of domestic market of antidiabetic drugs was conducted. According to the results of the analysis the assortment of medicines of the Ukrainian pharmaceutical market was described.

\section{Results and Discussion}

According to the international ATC classification antidiabetic drugs are referred to group A "Medicines affecting the digestive system and metabolism" and constitute a subgroup A10 "Antidiabetic drugs" [3]. According to the State Register of Medicines of Ukraine [1] it has been found that as of 01.10.2014 antidiabetic drugs comprise 206 trade names (without regard to the amount in the pack) among 12745 medicines registered in Ukraine. This group includes 49 drugs based 


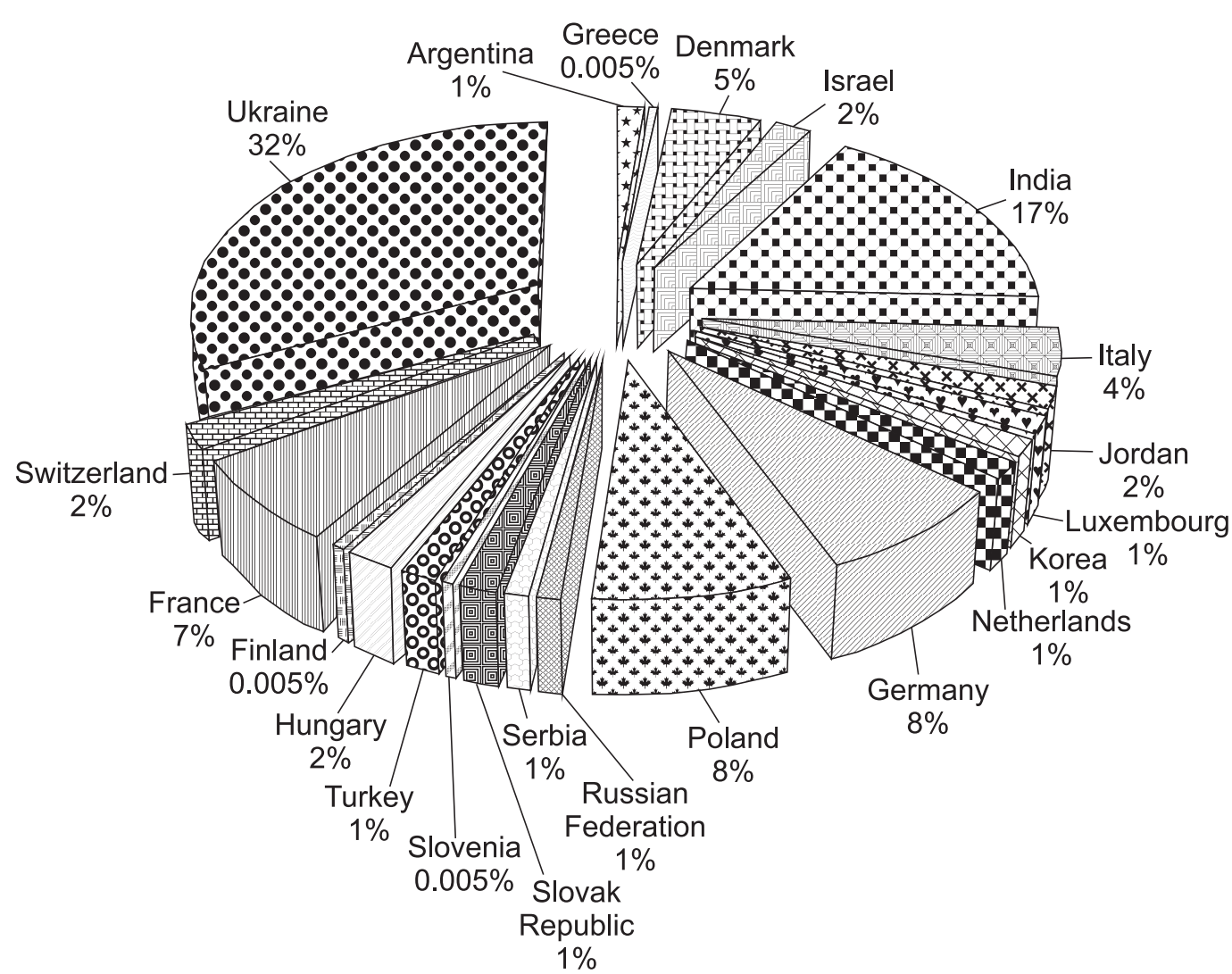

Fig. 1. The diagram of the ratio of antidiabetic drugs depending on the manufacturing country.

on insulin and its analogues for injection and 157 oral hypoglycemic drugs.

Only some representatives of each ATC-group for treating diabetes are registered at the pharmaceutical market of Ukraine. It should be noted that insulins are unevenly divided by the duration of action: 16 shortacting drugs, 14 drugs of the medium duration, and only 4 long-acting insulin medicines [14]. There are also 15 combinations of insulins with a short and medium duration of action for injection at the market. The overwhelming majority of all groups of insulins are presented by human insulin. Groups of insulin with a short and medium duration of action are characterized by individual representatives of porcine insulin $\left(\right.$ Monodar $\left.^{\circledR}\right)$, insulin lispro (Humalog ${ }^{\circledR}$ ) and insulin asparagine (Novorapid $^{\circledR}$ FlexPen $\left.{ }^{\circledR}\right)$. Long-acting insulins and their analogues for injection are presented by 3 drugs based on insulin glargine and one on insulin detemir $\left(\right.$ Levemir $^{\circledR}$ FlexPen ${ }^{\circledR}$ ).

Oral hypoglycemic drugs are characterized by more saturation within subgroups. There are 38 drugs based on metformin at the Ukrainian pharmaceutical market of biguanides. The drugs of glimepiride (about 50 names) are the widest presented as derivatives of carbamide. There is a sufficiently wide assortment of drugs based on gliclazide (16 positions). Sulfonamides are presented by 5 drugs of glibenclamide and 1 of gliquidone (Glyurenorm $^{\circledR}$ ). There are often combinations of oral hypoglycemic drugs [7] such as metformin and sulfonamides (12 medicines), metformin with sitagliptin (Yanumet ${ }^{\mathrm{TM}}$ ) and metformin with vildagliptin (GalvusMet $\left.{ }^{\circledR}\right)$. Thiazolidinediones are presented by 10 drugs on the basis of pioglitazone. Among the inhibitors of dipeptidyl peptidase-4 (dpp-4) [10] sitagliptin (Januvia ${ }^{\mathrm{TM}}$ ) appears three times, there is one vildagliptin (Galvus ${ }^{\mathbb{B}}$ ), and saxagliptin (Ongliza) is presented twice. Other hypoglycemic drugs, excluding insulins, also include drugs of guar gum (Guarem), repaglinide (NovoNorm ${ }^{\circledR}$ ) and liraglutide $\left(\right.$ Victoza $\left.^{\circledR}\right)$. Drugs of aldose reductase inhibitors (Isodibut under the trade name Isodibut ${ }^{\mathbb{R}}$ ) and other medicines, including 8 herbal medicines (based on fruits of Saint-Mary-thistle, the valves of the bean fruit, blueberry shoots or the mixture of crushed medicinal plant raw material), are also used to treat diabetes.

The results of the study of the assortment structure of antidiabetic drugs indicate that $68 \%$ of drugs are imported from 21 countries. Geography of manufacturing countries is quite extensive and includes the countries of the Eurasian and South American continents (Fig. 1). India occupies the leading positions and supplies 35 drugs of the group studied to Ukraine. A wide assortment of antidiabetic drugs is presented by Germany (16 trade names), Poland (16 names), France (14), Denmark (10) and Italy (8).

Data of the analysis in Fig. 1 indicate that the share of the Ukrainian producers of antidiabetic drugs is $32 \%$. However, most subgroups of antidiabetic drugs have no domestic analogues. The range of domestic drugs for treating diabetes is formed by 12 manufacturers.

It should be noted that in the list of drugs registered for treatment of diabetes distribution between manufacturing countries differs within the group. Thus, insulin and analogues for injection accounted $59.18 \%$ of the study group range and are characterized by a small 


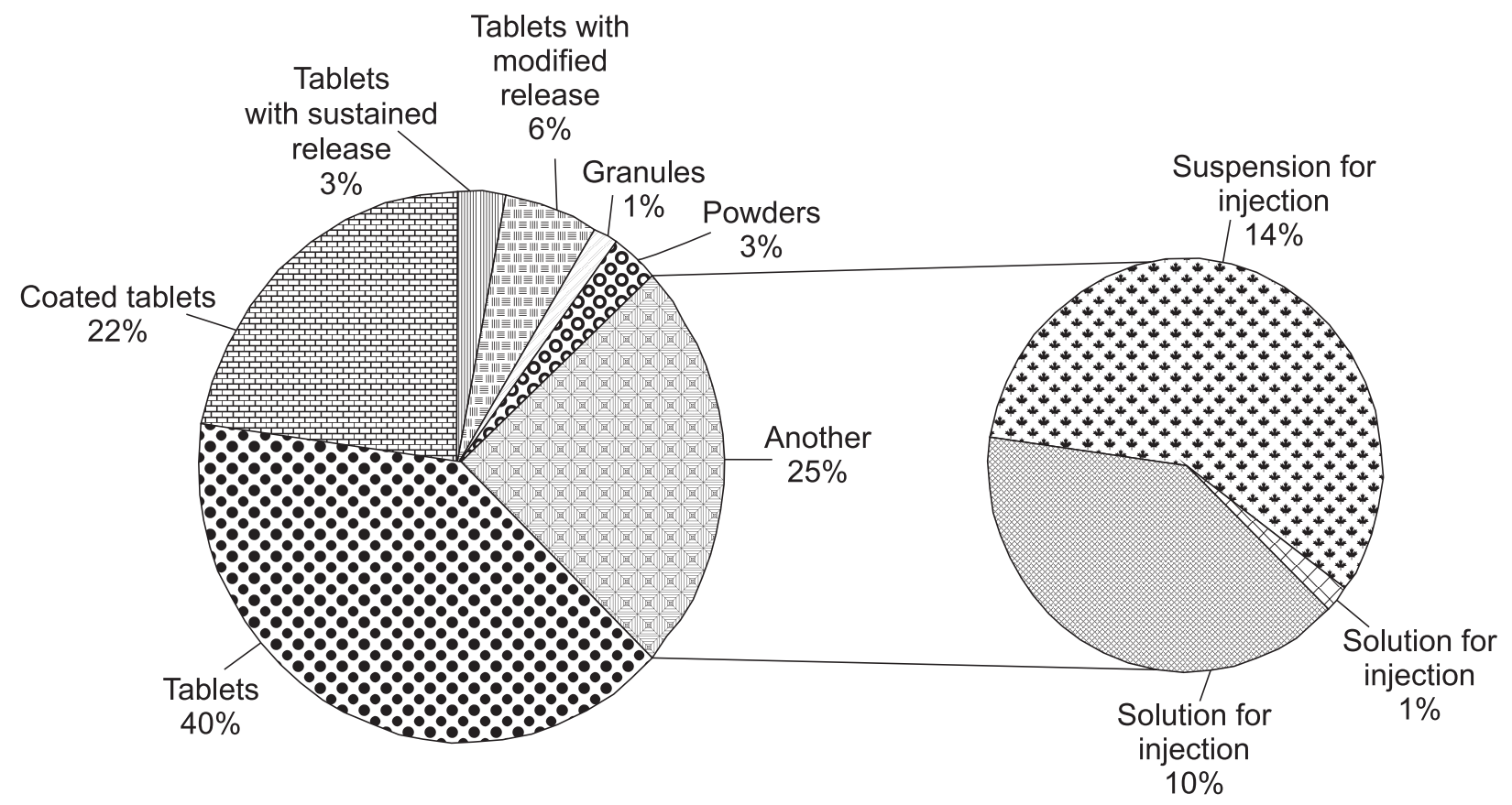

Fig. 2. Propositions of dosage forms of antidiabetic drugs at the pharmaceutical market of Ukraine.

number of countries. They are imported from of Denmark ("A/T Novo Nordisk" - 3), Poland ("Bioton S.A." 3), Germany ("Sanofi-Aventis Deutschland GmbH"-3). In addition, 3 finished medicinal products are manufactured by "Sanofi-Aventis Deutschland GmbH" (Germany), and "Pharma Life" Ltd. (Lviv, Ukraine), which is responsible for quality control and batch release, provides the secondary packaging. "Biocon Limited" (India) cooperates with "Darnitsa pharmaceutical company" JSC and supplies 3 drugs of this group at the Ukrainian market. The license holder of 2 insulin drugs manufactured by JSC "National biotechnology" (Russian Federation) is a domestic enterprise "UkrTerra LLC" (Kyiv, Ukraine). The Ukrainian insulin drugs and analogues for injection are manufactured by: "Indar" PJSC for production of insulin ( 7 drugs under such trade names as Humodar ${ }^{\circledR}$, Monodar $^{\circledR}$ ), "Farmak" OJSC (Farmasu$\operatorname{lin}^{\circledR} \mathrm{H}-6$ drugs), "Darnitsa pharmaceutical company" JSC (Insugen-R (Regulyar) Insugen-N (NPH), Insugen-30/70 (Bifazik) - 4), Pharmaceutical company "Zdorovye" Ltd. (Gensulin R-Zdorovya, Gensulin H-Zdorovya and Gensulin M30-Zdorovya - 3). There are no domestic analogues in groups of drugs containing insulin lispro, insulin asparagine, insulin glargin, insulin detemir.

Oral hypoglycemic drugs are mainly supplied at the Ukrainian market from abroad. The largest part of imported drugs for treatment of type 2 diabetes is offered by India, these are 32 drugs. A large number of drugs are offered by several companies from around the world, mainly from the European region, for which a high level of development of the pharmaceutical industry is typical. Poland takes $8.28 \%$ of the market segment of oral hypoglycemic drugs, Germany $-6.37 \%$, Italy and France $-5.10 \%$ each, Switzerland and Hungary $2.55 \%$ each. The Jordanian firm "Al-Hikma Pharmaceuticals" PLC manufactures drugs based on glimepiri- de $\left(\right.$ Glianov $\left.^{\circledR}\right)$. Drugs of metformin hydrochloride are imported in Ukraine by the Israel manufacturer "TEVA Pharmaceutical Industries Ltd". Three trade names of drugs are imported from Argentina, Luxembourg, Korea, Netherland, Slovakia, Turkey. "Galenika a.d." supplies 2 drugs from Serbia. Oral hypoglycemic drugs are imported in Ukraine from Greece, Denmark, Slovenia, Finland.

Along with highly effective medications the patients are deprived of the opportunity to take other drugs since there is a monopoly of some imported drugs. Domestic manufacturers offer only generic replacement of some active substance. The Ukrainian enterprises produce only 46 drugs on the basis of metformin hydrochloride, glibenclamide, gliclazide, glimepiride, a combination of metformin hydrochloride and glibenclamide, pioglitazone, isodibut and the medicinal plant raw material. Groups of isodibut and other drugs are formed only by domestic producers. The domestic enterprises producing drugs of these groups are: "Farmak" OJSC, Kyiv; "Kusum Pharm" LLC, Sumy; "Technologist" PJSC, Uman, Cherkasy region; "Pharmex Group" LLC, Boryspil, Kyiv region; "Pharma Start" LLC, Kyiv; Pharmaceutical company "Zdorovye" Ltd., Kharkiv; "Indar" PJSC for production of insulin, Kyiv; "Luhansk Chemical and Pharmaceutical Plant" JSC, Luhansk; "Liktravy" PJSC, Zhitomir; Pharmaceutical factory "Viola" PJSC, Zaporizhzhya; "Lubnypharm" JSC, Lubny, Poltava region.

At the pharmaceutical market of Ukraine antidiabetic drugs are available in a variety of dosage forms such as tablets, granules, powders, solutions and suspensions for injection. A tablet form is presented by common tablets, coated tablets, tablets with sustained release and tablets with modified release. All insulins and analogues for injection are produced in the form of solutions or suspensions. The results of analysis of the drug assortment presented in Fig. 2 indicate the dis- 
tribution of drugs by the dosage form and the route of administration taking into account the number of proposals for this form at the market.

Drugs of insulins and analogues for injection are available in two dosage forms. The suspension for injection is $59.18 \%$ of the assortment, $40.82 \%$ is in the form of the solution for injection. The suspension for injection is dispensed in bottles (17 positions), cartridges a carton box (20), cartridges inserted in multi-dosage disposable syringe pen (7). Among the solutions for injection 16 short-acting insulins and 4 long-acting drugs are proposed. Most of the drugs are produced simultaneously in several forms of packaging: in bottles - 9 trade names, in cartridges -10 , in cartridges built in sealed disposable syringe pens -5 and in syringe pens -3 .

Among the oral hypoglycemic drugs registered the solid dosage forms quantitatively prevail: tablets constitute $93.63 \%$, granules $-1.91 \%$, powders $-3.82 \%$, while the liquid dosage forms are only $0.64 \%$. This is due to ease of use and accuracy of dosing of tablets. Currently, there is a clear tendency to increase the efficiency of pharmacotherapy in the treatment of type 2 diabetes. Offers of tablet hypoglycemic drugs are divided between tablets ( 83 drugs), coated tablets (46), tablets with sustained release (6) and tablets with modified release. Twelve names of tablets based on gliclazide are produced with modified release of the active substance.

In a powder form there are 6 drugs based on the medicinal plant raw material, including the valves of the bean fruit, blueberry shoots, and 4 herbal teas. Granules are presented by 3 trade names. Guarem is produced in $5 \mathrm{~g}$ granules in packs and $500 \mathrm{~g}$ containers with a measuring spoon. Granules from fruits of Saint-Mary- thistle are produced under the brand names of Silysem $\AA$ and Gipoglisil ${ }^{\circledR}$. They are dispensed in single-dose bags, single-dose coupled bags and in jars with a measuring spoon. At the same time, hypoglycemic drugs are produced in the form of a solution for injection. Thus, Victoza $^{\circledR}$ is offered in cartridges inserted in pre-filled multi-dosage disposable syringe pen and in filled syringe pens in a carton box.

Thus, the studies conducted have shown that the market of antidiabetic drugs is characterized by heterogeneity of the product lines, high concentration and monopolization of manufacture, low competition and a small share of production of domestic drugs.

CONCLUSIONS

1. The marketing research of antidiabetic drugs presented at the pharmaceutical market of Ukraine has been conducted, and the structure of the product groups registered in Ukraine has been described.

2. The market of drugs for treating diabetes has been characterized according to the pharmacotherapeutic groups, manufacturing countries and dosage forms.

3. Quantitative and qualitative diversity of the current assortment of antidiabetic drugs presented by foreign companies and domestic manufacturers has been determined.

\section{REFERENCES}

1. Державний реєстр лікарських засобів Украйни - [Електронний ресурс]. - Режим доступу: httр://www. drlz.kiev.ua. - Назва з екрану.

2. Кирсанов Д. // Еженедельник «Аптека». - 2013. - №50 (921). - C. 18-19.

3. Компендиум 2011 - лекарственные препараты / Под ред. В.Н.Коваленко, А.П.Викторова. - К.: Морион, 2011. -2320 c.

4. Ларін О.С. // Міжнар. ендокринол. журн. - 2011. - №3 (35). - C. 10-19.

5. Паньків B.I. // Міжнар. ендокринол. журн. - 2013. - №7 (55). - C. 95-104.

6. Beagley J., Guariguata L., Weil C., Motala A.A. // Diabet. Res. Clin. Pract. - 2014. - Vol. 103, Issue 2. P. $150-160$.

7. Blackwell Publishing Ltd // Diabet. Med. - 2010. - Vol. 27. - P. 318-326.

8. Conway B.N., May M.E., Fischl A. et al. // Diabet. Med. - 2015. - Vol. 32 (1). - P. 33-41.

9. Danaei G., Finucane M.M., Lu Y. et al. // Lancet. - 2011. - 378 (9785) - P. 31-40.

10. Frandsen C.S., Madsbad S. // Diabet. Med. - 2014. - Vol. 31 (11). - P. 1293-1300.

11. Global status report on noncommunicable diseases 2010 / Ed. Ala Alwan. - Geneva: World Health Organization, 2011. $-176 \mathrm{p}$.

12. IDF. Diabetes atlas. Sixth ed. // Intern. Diabet. Federation. - 2013. - 160 p.

13. Mathers C.D., Loncar D. // PLoS Med. - 2006. - Vol. 3 (11). - P. 442.

14. Moses R.G., Bartley P., Lunt H. et al. // Diabet. Med. - 2009. - Vol. 26, Issue 3. - P. $260-267$.

15. Turner K.M., Percival J., Dunger D.B. et al. // Diabet. Med. - 2015. - Vol. 32 (2). - P. 250-256. 


\section{АНАЛІЗ АСОРТИМЕНТУ АНТИДІАБЕТИЧНИХ ПРЕПАРАТІВ НА ФАРМАЦЕВТИЧНОМУ РИНКУ УКРАЇНИ \\ О.В.Тригубчак \\ Ключові слова: діабет; лікарські засоби; асортимент; маркетингові дослідження;} фармацевтичний ринок

Проведені маркетингові дослідження антидіабетичних лікарських засобів, представлених на фрармацевтичному ринку України. Вивчено товарний асортимент групи антидіабетичних засобів згідно з АTC-класифрікацією, країнами виробниками та лікарськими фформами. За результатами аналізу охарактеризовано 49 препаратів на основі інсулінів і аналогів для ін'єкцій та 157 пероральних гіпоглікемічних лікарських засобів. Відмічено, що за тривалістю дії інсуліни розподілені нерівномірно. Більшість препаратів інсуліну представлена інсуліном людським. Пероральні гіпоглікемічні лікарські засоби характеризуються більшим насиченням у межах підгруп. Для лікування цукрового діабету також використовують препарати інгібіторів альдозоредуктази (ізодибут під торговою назвою «Ізодибут ${ }^{\circledR}$ ») та інші засоби, що включають 8 фрітопрепаратів. Встановлено, що 68\% препаратів антидіабетичних лікарських засобів імпортуються з 21 країни світу Євразійського та Південно-Американського континентів. Лідируючі позиції посідає Індія. Широкий асортимент антидіабетичних препаратів представлено з Німеччини, Польщі, Франції, Данії та Італії. Асортимент вітчизняних лікарських засобів для лікування цукрового діабету фоормють 12 фрірм-виробників. Вітчизняні виробники пропонують лише генеричні заміни деяких діючих речовин. На фрармацевтичному ринку України антидіабетичні препарати пропонуються у фрормі таблеток, гранул, порошків, розчинів та суспензій для ін'єкцій. Проведені дослідження показали, що ринок антидіабетичних лікарських засобів характеризується неоднорідністю асортиментних груп, високою концентрацією і монополізацією виробництва, низькою конкуренцією та незначною часткою випуску препаратів, яка припадає на вітчизняних виробників.

\section{АНАЛИЗ АССОРТИМЕНТА ПРОТИВОДИАБЕТИЧЕСКИХ ПРЕПАРАТОВ НА ФАРМАЦЕВТИЧЕСКОМ РЫНКЕ УКРАИНЫ О.В.Тригубчак \\ Ключевые слова: диабет; лекарственные средства; ассортимент; маркетинговые исследования; фрармацевтический рынок}

Проведены маркетинговые исследования противодиабетических лекарственных средств, представленных на фрармацевтическом рынке Украины. Изучен товарный ассортимент группы противодиабетических средств согласно АTС-классификации, стран-производителей и лекарственных форм. По результатам анализа охарактеризовано 49 препаратов на основе инсулина и аналогов для инъекций и 157 пероральных противодиабетических лекарственных средств. Отмечено, что по продолжительности действия инсулины разделены неравномерно. Большинство препаратов инсулина представлены инсулином человеческим. Пероральные гипогликемические лекарственные средства характеризуются большим насыщением в пределах подгрупп. Для лечения сахарного диабета также используют препараты ингибиторов альдозоредуктазы (Изодибут под торговым названием «Изодибут $»)$ и другие средства, включающие 8 фритопрепаратов. Установлено, что 68\% препаратов противодиабетических лекарственных средств импортируются из 21 страны мира Евразийского и Юго-Американского континентов. Лидирующие позиции занимает Индия. Широкий ассортимент противодиабетических препаратов представлен из Германии, Польщи, Франции, Дании и Италии. Ассортимент отечественных лекарственных средств для лечения сахарного диабета фрормируют 12 фрирм-производителей. Отечественные производители предлагают только генерические замены некоторых действующих веществ. На фрармацевтическом рынке Украины противодиабетические препараты предлагаются в форме таблеток, гранул, порошков, растворов и суспензий для инъекций. Проведенные исследования показали, что рынок противодиабетических лекарственных средств характеризуется неоднородностью ассортиментных групп, высокой концентрацией и монополизацией производства, низкой конкуренцией и незначительной долей выпуска препаратов, приходящейся на отечественных производителей. 